\title{
Research Paper Cabbage production in Kolar district of Karnataka : An economic analysis
}

See end of the paper for authors' affiliations

Correspondence to :

R. Raghupathi

Department of Agricultural Economics,University of Agricultural Sciences, G.K.V.K., Bengaluru (Karnataka) India Email : raghupathir48@ gmail.com
Paper History :

Received : 01.12.2017;

Revised : 09.01.2018;

Accepted : 23.01 .2018
ABSTRACT : India is the second largest producer of vegetables in the world next to China. The cabbage is the major vegetable crop of Karnataka. The study was conducted in kolar district on cost of cultivation and returns on different cost concepts basis of cabbage. The result reveled that, production is normally considered as the function of area and yield. The decision regarding the choice of crop enterprise to be taken on the farm and the allocation of area and resources under it depends to a great extent, on level of yield, price of output and the cost of inputs used in the production of that crop. The cost of cultivation and the returns to different factors of production help in decision making about the selection of crop and hence, these measures were worked out for cabbage. On an average, Rs. 42,873 was spent on cabbage per hectare. Cost of cultivation of by the small size farms were high (Rs. 44671/ha) as followed by medium and large size farms (Rs.42002/ha and Rs.41946/ha). And the cost of production per quintal in different size of farms group was Rs.669.43/ha, respectively. The cabbage price per quintal in market was Rs.1700. The sample average for $\operatorname{Cost} \mathrm{A}_{1}, \operatorname{Cost} \mathrm{A}_{2}, \operatorname{Cost} \mathrm{B}$ and Cost C in different farms size groups were Rs.30453/ha, Rs.33953/ha and Rs. 37906/ha and Rs.42873/ ha, respectively. And farm business income and family labour income in different size of farms group were Rs.75010/h and 755540/ha. An average of net return obtained from cabbage growers per hectare was Rs. 62504/ha.

KeY Words : Cabbage, Cost returns, Cost of cultivation, Cost of production, Returns

How To Cite This PAPer : Raghupathi, R. and Kumar, Sanjay (2018). Cabbage production in Kolar district of Karnataka : An economic analysis. Internat. Res. J. Agric. Eco. \& Stat., 9 (1) : 53-57, DOI : 10.15740/HAS/ IRJAES/9.1/53-57. 